\title{
A Study on the Influence of Institutional Investor Heterogeneity on the Executive Pay Stickiness_— Based on the Perspective of Industrial Factor Intensity
}

\author{
Qitong $\mathrm{Yu}^{1}$, Shaoyang Fang ${ }^{1} \&$ Jianjun Wang ${ }^{2}$ \\ ${ }^{1}$ School of International Business, Jinan University, Zhuhai, Guangdong Province, China \\ 2 School of Accounting, Chongqing University of Technology, Chongqing, China \\ Correspondence: Qitong Yu, Finance Department of International Business School, Jinan University, Qianshan \\ Road 206\#, Zhuhai City, Guangdong Province, Post No. 519070, China. E-mail: m15277168421@163.com
}

Received: August 5, 2018

Accepted: August 25, 2018

Online Published: August 30, 2018

doi:10.5539/ijef.v10n9p168

URL: https://doi.org/10.5539/ijef.v10n9p168

\begin{abstract}
Based on the data of Shanghai and Shenzhen A-share listed companies from 2012-2016, this paper empirically studies the influence of heterogeneous institutional investors on executive compensation stickiness of listed companies by using the method of multiple regression. The results show that the pay stickiness is very common in the listed companies. The overall institutional investor's shareholding is promoting the executive compensation stickiness. The empirical results show that the institutional investors are divided into the pressure resistance institutional investors and the pressure sensitive institutional investors, according to whether the institutional investors have the commercial relationship with the listed companies. The empirical results show that they are compared to the pressure. Sensitive institutions, pressure resistance institutional investors can significantly inhibit the stickiness of executive compensation. However, different types of institutional investors have different preferences for the types of listed companies, and the enthusiasm of participating in corporate governance is different, and the pressure resistance institutional investors pay more attention to labor out of social responsibility. The long-term performance of a force intensive enterprise has a significant inhibitory effect on the stickiness of the executive compensation, while the pressure sensitive institutional investors actively manage and supervise the production and operation of the technology intensive enterprises for the consideration of the investment income, which has a restraining effect on the pay stickiness of the technology intensive enterprises.
\end{abstract}

Keywords: institutional investor heterogeneity, executive pay stickiness, factor intensity

\section{Introduction}

In December 2017, the news that Evergrande Group hired Ren Zeping as chief economist with a salary of 15 million per year dominated the headlines in Weibo, WeChat and other major media outlets, sparking huge controversy in the community. Prior to this, high executive compensation has been the focus of academic and practical circles at home and abroad. The average executive compensation for listed companies was 636100 yuan in 2012, 3.5308 million yuan in 2015 and 2.9676 million yuan in 2016, according to data released by Sina Technology. Although 2016 to 2 The decline was marked in 015, but the increase was more than 360, compared with 2012. According to a 2015 U.S. statistic, the average executive pay of the top 500 companies in the United States is 1000 times that of an average American worker, and the gap continues to widen. So what causes executives' pay to climb year after year, leaving ordinary workers out of reach?

As an agent of shareholders, senior managers have a close relationship with the level of execution and the realization of the goal of maximizing the value of shareholders. They hold the most confidential information within the company. They have the best understanding of the organizational structure and operating mechanism of the company. They make the corresponding decisions and implement them according to the market trend. However, because the goals of shareholders and executives are different, there are principal-agent problems such as asymmetric information and adverse selection between the two sides, which often lead to executives having the motive and the ability to make short-sighted behavior in pursuit of immediate interests, and even "hollowing out" companies in association with major shareholders, thus infringing on small and medium-sized investments. 
In the guidelines on Corporate Governance issued by the China Securities Regulatory Commission and the State Economic and Trade Commission in 2002, it is clearly stipulated that listed companies should establish an incentive mechanism for managers' compensation to be linked to corporate performance and individual performance. In the way of compensation contract, executives are encouraged to make beneficial shareholder behavior decisions to avoid managers acting against the wishes of the client. However, the compensation contract does not necessarily achieve the ideal purpose, which often deviates from the original intention of the optimal contract design because of various factors. Behind the compensation contract, it embodies more traces of the executive compensation, and they have the ability to use the rights of managers to influence their own compensation design and rent (Bebchunk, 2002). The pay increased significantly, while the decline in salary declined even when the performance fell. Jackson et al. (2008) calls the "pay stickiness" a phenomenon in which the marginal increase in executive compensation is greater than the marginal decrease in the performance decline. It can be seen that, although the compensation mechanism can reduce the cost of principal-agent, under the premise of the assumption of "economic man", when the performance of the enterprise rises, the executives will ask for credit to a greater extent for the purpose of personal interest, thus obtaining the high compensation; And when their performance drops, they use the "attribution" method, using the external market environment and the macroeconomic situation as an excuse to avoid a sharp drop in compensation (Zhang, Sang, \& Lu, 2016). At this time, the sensitivity of executive compensation and corporate performance decreases, viscosity increases, which will not only affect the corporate governance efficiency, but also will involve the protection of the interests of small and medium-sized investors, which is not conducive to the stable operation and healthy development of the capital market. Therefore, relying on the compensation mechanism alone can not effectively motivate and supervise the executives simultaneously, and the behavior of the executives pursuing the maximization of short-term compensation may bring greater risks to the enterprises. When incentives need to take on greater risks, direct supervision is used (Shin, 2008). Previous studies have shown that direct shareholder supervision and managers' incentive mechanisms are complementary (Almazan, 2005). But due to the limited voting rights of minority shareholders, the information transparency and equity structure of listed companies are the factors that affect the voting enthusiasm of minority shareholders (Li \& Kong, 2013). When they find that there is no difference between the expected returns of supervision and non-supervision, they tend to show "rational apathy" or choose "vote with their feet" (Zheng \& Xu, 2013). While financial and non-financial institutions, as professional investors, are more capable and motivated to focus on the long-term performance of enterprises, playing a more active and effective role for the governance structure and oversight mechanisms, as an external supplement, institutional investors in the internal regulation of companies has attracted more and more attention. Over the past 20 years, institutional investors have played an important role not only in the capital markets of developed countries, but also in emerging markets (Khorana, Servaes, \& Tufano, 2005). Some scholars say that institutional investors may be the appropriate context for the relationship between shareholder oversight mechanisms and manager incentives because executive compensation is one of the internal governance issues that institutional investors are concerned about. Institutional investors can directly or indirectly influence compensation contracts and improve the effectiveness of executive incentives (Zhang \& Jiang, 2010; Wu, 2015).

The existing literature has explored the mechanism of its effect on executive pay stickiness more from internal control, equity structure and other internal factors or external audit, analysts' concern and market-oriented process. Few literatures study the impact of investment institution shareholding on executive compensation from the perspective of institutional heterogeneity. And the importance of physical capital, human capital and other factors of production in different industries are different. This affects internal corporate governance and performance ( $\mathrm{Li} \& \mathrm{Ye}$, 2007), which in turn has an impact on the choice of institutional stock. There is no industrial clustering of listed companies in the literature to distinguish the preference of institutional investors for listed stocks under different factor intensity. Therefore, this paper takes the Shanghai and Shenzhen A-share listed companies from 2012-2016 as the research object, from the perspective of institutional characteristics, explores the overall impact of institutional shareholding on executive pay stickiness, and subdivides the institutions into stress-resistant institutions and pressure-sensitive institutions. This paper discusses the relationship between the two types of institutions and the stickiness of executive compensation in different factor intensive enterprises.

The possible contributions of this paper are as follows: (1) this paper sets up a perfect model with the characteristics of the listed companies' own characteristics for the heterogeneity of institutional ownership, factor density, and executive compensation stickiness, revealing the relationship between the three parties and the internal differences, which is a useful supplement to the existing literature on the influencing factors of executive compensation. (2) Based on the economic background of China's emerging capital markets, this paper probes into how institutional investors, as important participants in capital markets, as external supervisors, influence 
the sensitivity of executive compensation to performance. According to the characteristics of institutional investors and the commercial relationship with listed companies, the paper expands and enriches the relevant theories and studies of compensation contract supervision from the perspective of external investors, and guides different types of institutional investors to play a more active role in the construction and improvement of China's capital market. (3) this paper will discuss the investment institutions' density of different factors from a new visual angle. The preference of enterprises and the regulation effect on the internal governance efficiency of listed companies provide guidance for future listed companies to formulate internal governance supervision mechanism and make full use of external supervision to realize the win-win between managers and shareholders.

\section{Theoretical Analysis and Research Hypothesis}

\subsection{Institutional Investors' Shareholding and Executive Compensation}

In the broad corporate governance framework, executive compensation incentive plan and external supervision of institutional investors constitute a complementary mechanism, which to some extent controls the principal-agent problem between managers and shareholders. To some extent, effective compensation contract can alleviate the principal-agent problem between shareholders and executives. However, it is common for executives to use the right of management to set their own compensation for private purposes. The asymmetry in pay movements lead to higher or lower corporate performance. Lu (2008) and Fang (2009) have verified the asymmetric characteristics of executive compensation performance sensitivity of listed companies in China. Wang (2007) considered that the low transparency of information disclosure in the process of making and implementing executive compensation plans is an important reason for increasing the possibility of executive compensation stickiness. Therefore, as an important external supplement, institutional investors play a more important role in corporate governance.

In recent years, with the rapid development of securities investment funds, social security funds, collective asset investment plans and other institutional investors have gradually become important participants in the capital market. Governments have also begun to attach importance to the role of institutional investors in corporate governance. About the role of institutional investors in corporate governance, pound put forward three hypotheses (Pound, 1988): effective supervision, conflict of interest and strategic alliance. Individual investors in the securities market are extremely scattered and weak (Shleifer \& Vishny, 1986), the cost of supervision is high and easy to "hitchhike" behavior, so many small and medium-sized investors take a more negative attitude to the supervision and management of the enterprises held by them. The hypothesis of effective supervision holds that institutional investors hold more shares of listed companies than individual investors, which have the advantages of scale and information resources. Investors will actively participate in the investment decisions and internal governance of listed companies, improve the internal control system and supervision and incentive mechanism, and improve the overall governance level of enterprises. From the perspective of principal-agent theory, large institutional shareholders have the opportunity to obtain more internal information related to corporate governance from the management. And large institutional shareholders act as an information intermediary to communicate this private information to other shareholders and stakeholders (Wang, Liu, \& Wang, 2018), to reduce the cost of information and supervision for small and medium-sized investors. To some extent, it alleviates the principal-agent problem caused by asymmetric information between shareholders and management (Chen, Song, \& Lou, 2007).

However, existing studies show that institutional investors tend to conflict of interest and strategic collusion hypothesis. There is a double principal-agent relationship between institutional investors and listed companies. As an agent of indirect investors, institutions gather the scattered funds to invest in all kinds of securities portfolios. As an agent of direct investors, the listed companies use the funds raised in the production and operation activities such as fixed assets construction, development of innovative technologies and other activities within the company. Not only do institutional investors, under pressure from their own performance, support the irrational behavior of the management, but they may also have some kind of business relationship with the listed companies. It is precisely because of the complex principal-agent relationship between listed companies and shareholding institutions that institutional investors are motivated to make choices that are contrary to collective action, resulting in agency risk (Yang, 2016), which leads to the failure of listed companies to obtain effective external supervision. Managers have the opportunity to design and implement a set of "performance, new pay, performance, pay no less" salary incentive plan, to pursue their own short-term benefits maximization. Bhide (1993) found that institutional investors support and even encourage executives to pursue short-term interests, and then damage the long-term interests of companies and other shareholders. David (1996) also indicates that there are both investment and business relations between the investment institutions and the listed companies, and their dual identity will cause conflicts of interest. This will reduce the intervention and impact of investment 
institutions on the internal governance of listed companies. Under the control of interest, institutional investors choose to form strategic alliances with corporate executives to conspire to damage the long-term interests of the company. Because the investment of the institution has a certain short-term nature, and the strategic cooperation with the shareholding company can maximize the value of its objective function (Luo, 2016). In addition, Lerner (1995) proposed that the intervention of government "visible hand" makes the investment behavior of institutional investors subject to various institutional conditions (Lerner, 1995). Yan Liming et al. (2015) also found that government intervention reduced the enthusiasm of institutional investors to intervene in the company and had a negative impact on corporate governance. And the greater the government intervention is, the more restricted the role of institutional investors in supervising the internal operation of the company. As our country is still in the primary stage of socialism at the present stage, the construction of the capital market system is still in its infancy and the various systems have not yet been perfected. The government has intervened more in the behavior of the main body of the financial market. The government often limits the amount of a single investment by an institutional investor, or the proportion of shares held by an investment institution in a listed company, to avoid greater commercial relevance between the institutional investor and the shareholding company. However, strong administrative intervention can also restrain the enthusiasm of institutional investors in corporate governance, which can not play an incentive role in the function of external supervision of institutional investors, and reduce the effectiveness of the supervisory mechanism of senior leaders. On this basis, this paper proposes hypothesis 1 :

H1: executive compensation stickiness is common in listed companies in China, and institutional investors' shareholding is positively correlated with compensation stickiness.

\subsection{Heterogeneous Institutional Investors and Executive Compensation}

Because of the heterogeneity of investment preference, investment purpose, investment duration and risk preference among institutional investors, each investment institution will have different supervision measures and management methods. The enthusiasm for participating in the internal governance of the company will also vary according to the relationship between transaction gains and costs. Based on the signaling theory, the behavior of institutional investors who are actively involved in the internal management of the company will become a "wind vane" in the capital market. The investment ratio is important reference information for individual investors in stock trading (Bemard, 1992), while institutional investors who choose "vote with their feet" or "rational apathy" will become followers of interest. If there is a conflict of interest between the institutional investor and the listed company, then the investment institution may collude with the management in order to achieve its own performance objectives, encouraging the management to pursue short-term interests, thereby harming the long-term interests of the company. Have a negative impact on the efficiency of the company's internal governance. However, institutional investors who do not have a conflict of interest with listed companies will exercise their duties with due diligence, independently and objectively perform their duties of external supervision, prudently supervise the quality of financial information disclosure of listed companies and the compliance management of managers. Effectively prevent executives from magnifying rewards and avoiding self-interest behavior of punishment.

Therefore, according to the viewpoint of Brickley (1988) and whether there is any conflict of interest and business relationship between institutional investors and listed companies, this paper divides institutional investors into stress-resistant investors and stress-sensitive investors. There is no conflict of interest or business relationship between pressure-resistant institutional investors and listed companies, including securities investment funds, qualified foreign institutional investors (QFII) and social security funds. Despite the "hype" and "share-sitting" of a few fund companies, securities investment funds as a whole still play the role of active investors (Xiao \& Wang, 2005), the supervision behavior is independent of the outside influence. QFII has strong value choice ability (Song \& Tang, 2009), mainly with long-term investment, pays attention to the enterprise's basic aspect analysis, therefore pays more attention to the enterprise internal governance and the long-term performance. The social security fund adopts the mode of entrustment management and parent fund operation, and rarely communicates with the listed company in private, and does not interfere with the change of microcosmic shareholding (Chen, 2017). There is a close business relationship between stress-sensitive institutional investors and the listed companies they own. The investment behavior of stress-sensitive investors is likely to lead to conflicts of interest, leading institutions to abandon the authority to oversee the management of the enterprise and choose business practices that maximize utility functions, including securities firms, insurance, trusts, finance companies, banks, Non-financial institutions and other institutional investors. There is only investment relationship between pressure-resistant investors and listed companies which focus on value investment and long-term investment and pay more attention to the long-term performance of enterprises. This 
gives pressure resistant institutional investors the incentive to participate in the internal control system of listed companies. Measures should be taken to improve the quality of financial information disclosure, to effectively exert the function of external supervision, to reduce the self-interest behavior or opportunistic behavior of management personnel, and to alleviate the principal-agent problem between shareholders and executives. Stress-sensitive financial institutions such as insurance and trusts tend to have business partnerships with listed companies they own and may benefit from existing or potential commercial relationships, which triggers a "strategic alliance" between investment institutions and management personnel, and tend to turn a blind eye to or support corporate management decisions (Yu, Lu, \& Xie, 2017), giving management the opportunity to exaggerate when performance rises due to their own credit. The pressure sensitive institutional investors can not make objective and fair judgment and play a good external supervision role in the investment decision of the company. On this basis, this paper proposes hypothesis 2 :

H2: Compared with pressure-sensitive investors, pressure-resistant investors have a more significant inhibitory effect on executive pay stickiness in listed companies, but pressure-sensitive investors have no significant or even negative effects on executive compensation stickiness.

\subsection{Factor Intensity and Heterogeneity of Institutional Investors}

Different types of institutional investors often exhibit different investment preferences, which in turn affect the enthusiasm of institutions to participate in corporate internal governance. Different types of listed companies will also show different long-term performance due to the attention of heterogeneous institutional investors. Therefore, it is necessary to classify the listed companies and discuss the impact mechanism of institutional investors on executive pay stickiness of listed companies. The most commonly used industry classification method is classified by the factor intensity index proposed by Swedish scholars Herkhill and Olin. Factor intensity represents the relative proportion of each factor input in an industry, and can reflect the production characteristics of the industry (He, Fang, \& Feng, 2017). Referring to the classification indexes of (Lu \& Dang, 2014), this paper divides the industries of listed companies into three industries: labor-intensive, technology-intensive and capital-intensive.

Generally speaking, labor-intensive industries often have disadvantages such as inefficient production, redundant personnel in departments, and so on. The value of enterprises can only be measured by human resources, existing production technology and market scale. Especially in the critical period of economic transformation in China and even the world, the advantages gained by the low labor costs in the past are gradually being lost. With the rapid development of AI technology in recent years, it is widely believed that artificial intelligence will replace most of the personnel positions, and the labor-intensive industry is in a precarious state. If technological innovation is not used to promote the breakthrough in productivity, with the development of the times, the trend of transformation and upgrading will be faced with the possibility of bankruptcy at any time. In recent years, the vigorous development of institutional investors has benefited from a series of policies and measures to encourage and develop institutional investors, and the institutionalization of the main body of the securities market has become increasingly obvious. In order to give back the support of society, the pressure resistance organization is aware that it is not enough only to pay attention to the return of investment. The relationship between social performance and corporate financial performance will also be the economic return of the investment institution (Cox, Brammer, \& Millington, 2007). Therefore, it is incumbent on them to take on more social responsibilities, to take the initiative to pay attention to and hold the shares of inefficient labor-intensive enterprises, and to take part in the internal governance of the company to help the loss-making companies turn from losses to profits. To support and encourage R \& D innovation of core staff, to improve production efficiency and have long-term and stable production capacity; to supervise the behavior of management personnel and effectively avoid the possibility of negative slack and opportunism. The stress-sensitive investment institutions which have commercial relations with listed companies pay more attention to the real return on investment and the benefits brought by the commercial relationship. The listed companies with core $R \& D$ capabilities are often the focus of their attention. The pressure-sensitive investment institutions can be informed of the internal research and development status and the degree of importance attached to technological innovation by the listed companies' $R \& D$ expenditure and the number of patent applications, so as to judge the intrinsic value and potential development ability of the company and look for opportunities to actively participate in the company's internal governance to obtain more relevant information. Capital-intensive industries tend to be asset-intensive enterprises, as assessed by asset appraisal reports The net asset value of the enterprise directly constitutes the vast majority of the enterprise value, therefore, for capital-intensive industries listed companies, institutional investors are less active in management and supervision than other industries. On this basis, hypothesis 3 is proposed: 
H3a: Compared with technology-intensive and capital-intensive enterprises, pressure resistant institutional investors have a more significant restraining effect on executive pay stickiness of labor-intensive enterprises.

H3b: Compared with labor-intensive and capital-intensive enterprises, stress-sensitive institutional investors have a more significant inhibitory effect on executive pay stickiness in technology-intensive enterprises.

\section{Method}

\subsection{Sample Selection and Data Source}

The paper selects Shanghai and Shenzhen A-share listed companies as sample companies from 2012-2016, and selects the samples as follows: (1) excluding financial companies; (2) excluding St companies; (3) excluding companies with missing data, and finally obtaining 8491 effective observation samples. The empirical part uses Eviews8.0 software, the main source of data is Cathay Pacific database.

\subsection{Model construction and variable design}

The basic models of Leone (2006) and Xia Xue (2014) verify these hypotheses:

$$
\begin{aligned}
& y 1_{i, t}=\beta_{0}+\beta_{1} * \operatorname{roe}_{i, t}+\beta_{2} * d_{i, t}+\beta_{3} * \operatorname{roe}_{i, t} * d_{i, t}+\beta_{4} * \operatorname{cont}_{i, t} \\
& y 1_{i, t}=\beta_{0}+\beta_{1} * \operatorname{roe}_{i, t}+\beta_{2} * d_{i, t}+\beta_{3} * \operatorname{roe}_{i, t} * d_{i, t}+\beta_{4} * \text { ins }_{i, t}+\beta_{5} * \operatorname{ins}_{i, t} * \operatorname{roe}_{i, t}+ \\
& \beta_{6} * \text { ins }_{i, t} * \operatorname{roe}_{i, t} * d_{i, t}+\beta_{7} * \operatorname{cont}_{i, t} \\
& y 1_{i, t}=\beta_{0}+\beta_{1} * \operatorname{roe}_{i, t}+\beta_{2} * d_{i, t}+\beta_{3} * \operatorname{roe}_{i, t} * d_{i, t}+\beta_{4} * \operatorname{res}_{i, t}+\beta_{5} * \operatorname{res}_{i, t} * \operatorname{roe}_{i, t}+ \\
& \beta_{6} * \operatorname{res}_{i, t} * \operatorname{roe}_{i, t} * d_{i, t}+\beta_{7} * \operatorname{cont}_{i, t} \\
& y 1_{i, t}=\beta_{0}+\beta_{1} * \operatorname{roe}_{i, t}+ \beta_{2} * d_{i, t}+\beta_{3} * \operatorname{roe}_{i, t} * d_{i, t}+\beta_{4} * \operatorname{sen}_{i, t}+\beta_{5} * \operatorname{sen}_{i, t} * \operatorname{roe}_{i, t}+ \\
& \beta_{6} * \operatorname{sen}_{i, t} * \operatorname{roe}_{i, t} * d_{i, t}+\beta_{7} * \operatorname{cont}_{i, t}
\end{aligned}
$$

Among them, $y 1$ is the logarithm of the top three executive compensation packages, roe is performance variable, cont is a set of control variables, $\beta_{1}$ is the extent to which executive pay rises when performance rises, $\beta_{1}+\beta_{3}$ is the decline in executive pay when performance falls. The article anticipates $\beta_{1}+\beta_{3}<\beta_{1}$, executive pay rises when results rise than executive pay falls when results fall, confirming the existence of

\begin{tabular}{|c|c|c|}
\hline Variables & Symbol & Definition \\
\hline \multirow[b]{2}{*}{ Executive compensation } & $y_{1}$ & Logarithm of top three executive compensation totals \\
\hline & $y_{2}$ & $\begin{array}{l}\text { Logarithm of the total remuneration of the top three } \\
\text { directors, supervisors and executives }\end{array}$ \\
\hline corporate performance & roe & Return on net assets \\
\hline Decline in performance & $d$ & $\begin{array}{l}\text { If the company's results are down from the previous year, } \\
\text { take } 1 \text { or } 0 .\end{array}$ \\
\hline institutional shareholdings & ins & Total number of institutional investors holding shares \\
\hline Pressure resistant institutional investors & res & $\begin{array}{c}\text { Number of pressure-resistant institutional investors } \\
\text { holding shares }\end{array}$ \\
\hline Pressure-sensitive institutional investors & sen & $\begin{array}{c}\text { Number of shares held by stress-sensitive institutional } \\
\text { investors }\end{array}$ \\
\hline Separation of two posts & dual & $\begin{array}{c}\text { The chairman of the board of directors shall take } 1 \text { when he } \\
\text { is also the general manager, otherwise he will take } 0\end{array}$ \\
\hline Independent director ratio & board & Proportion of independent directors to total directors \\
\hline Property nature & state & 1 for state-owned property, 0 for otherwise \\
\hline company size & revenue & Annual operating income \\
\hline asset-liability ratio & lev & Ratio of liabilities to assets at year-end \\
\hline Equity concentration & first & Proportion of first largest shareholder \\
\hline Executive stock holding & hold & Number of shares held by senior executives \\
\hline Year & year & Virtual variables used to control macroeconomic impacts \\
\hline
\end{tabular}
executive pay stickiness. In addition, this paper also predicts that $\beta_{6}$ is significantly negative, thus validating hypothesis $\mathrm{H} 1$ and hypothesis $\mathrm{H} 2$. On the proof of hypothesis $\mathrm{H} 3$, this paper will adopt the method of cluster analysis, group the listed companies according to the concentration of production factors and carry on regression, and compare the significance of the above coefficients. Specific definitions of other variables are given in Table 1.

Table 1. Variables 
Table 2. Sample distribution

\begin{tabular}{|c|c|c|c|c|c|c|c|c|}
\hline & \multicolumn{2}{|c|}{ Labor-intensive enterprises } & \multicolumn{2}{|c|}{ technology-intensive enterprise } & \multicolumn{2}{|c|}{ capital intensive enterprise } & \multicolumn{2}{|c|}{ sum } \\
\hline & $\begin{array}{c}\text { sample } \\
\text { capacity }\end{array}$ & proportion & $\begin{array}{l}\text { sample } \\
\text { capacity }\end{array}$ & proportion & $\begin{array}{c}\text { sample } \\
\text { capacity }\end{array}$ & proportion & $\begin{array}{l}\text { sample } \\
\text { capacity }\end{array}$ & proportion \\
\hline 2012 & 606 & $37.85 \%$ & 733 & $45.78 \%$ & 262 & $16.36 \%$ & 1601 & $100.00 \%$ \\
\hline 2013 & 573 & $37.57 \%$ & 710 & $46.56 \%$ & 242 & $15.87 \%$ & 1525 & $100.00 \%$ \\
\hline 2014 & 632 & $37.89 \%$ & 777 & $46.58 \%$ & 259 & $15.53 \%$ & 1668 & $100.00 \%$ \\
\hline 2015 & 680 & $37.86 \%$ & 850 & $47.33 \%$ & 266 & $14.81 \%$ & 1796 & $100.00 \%$ \\
\hline 2016 & 707 & $37.19 \%$ & 902 & $47.45 \%$ & 292 & $15.36 \%$ & 1901 & $100.00 \%$ \\
\hline
\end{tabular}

\section{Result}

\subsection{Industry Cluster Analysis}

On the basis of the industry classification of CSRC, taking the proportion of fixed assets and R \& D expenditure as indicators, clustering analysis is carried out according to the factor intensity, studies the effect of heterogeneous institutional ownership on executive pay stickiness in labor-intensive, technology-intensive and capital-intensive enterprises.

$$
\text { Ratio of fixed assets }=\text { net fixed assets/total assets }
$$

Proportion of $R \& D$ expenditure $=R \& D$ expenditure/employee pay payable

The larger the proportion of fixed assets is, the more important the fixed assets play in the production process, so it is a capital-intensive enterprises. The higher the proportion of R\&D expenditure, the more attention the management attaches to the development of new technology and new products, so it is a technology-intensive enterprise. Otherwise, it is a labor-intensive enterprise. On the basis of calculating the proportion of fixed assets and R\&D expenditure, SPSS22.0 is used to cluster analysis.

Table 3. Results of industry cluster analysis

\begin{tabular}{|c|c|c|}
\hline & & \\
\hline $\begin{array}{l}\text { industry; wholesale industry; } \\
\text { manufacturing industries; petrole } \\
\text { processing, Keywords coking and nuc } \\
\text { fuel processing industry; } \\
\text { manufacturing; general equipm } \\
\text { manufacturing; civil engineer } \\
\text { construction; culture and art; culture } \\
\text { education; arts and industry; sports }\end{array}$ & $\begin{array}{l}\text { Electricity, thermal production and } \\
\text { supply; electrical machinery and } \\
\text { equipment manufacturing; textile, } \\
\text { clothing, clothing; ferrous metal smelting } \\
\text { and calender processing; chemical fibre } \\
\text { manufacturing; chemical raw materials } \\
\text { and chemical products manufacturing; } \\
\text { computers, Communications and other } \\
\text { electronic equipment manufacturing; } \\
\text { building decoration and other } \\
\text { construction; automotive manufacturing; } \\
\text { software and information technology } \\
\text { services; ecological protection and } \\
\text { environmental governance; railways, } \\
\text { ships, aerospace and other transport } \\
\text { equipment manufacturing; } \\
\text { Pharmaceutical manufacturing industry; } \\
\text { professional technical service industry; } \\
\text { special equipment manufacturing } \\
\text { industry }\end{array}$ & $\begin{array}{l}\text { road transport; telecommunications, radio } \\
\text { and television and satellite transmission } \\
\text { services; radio, television, film and film } \\
\text { recording operations; air transport; ferrous } \\
\text { metal mining; furniture manufacturing; } \\
\text { education; wine, Beverage and refined tea } \\
\text { manufacturing; forestry; coal mining and } \\
\text { washing; wood processing and wood, } \\
\text { bamboo, rattan, brown, grass products; } \\
\text { agriculture, forestry, animal husbandry, } \\
\text { fishing services; agriculture; leather, fur, } \\
\text { feathers and their products and footwear; } \\
\text { Gas production and supply; business } \\
\text { services; oil and gas extraction; water } \\
\text { production and supply; water transport; } \\
\text { sanitation; press and publishing; } \\
\text { researchAnd experimental development; } \\
\text { printing and recording; reproduction; } \\
\text { non-ferrous metal mining and separation; } \\
\text { fisheries }\end{array}$ \\
\hline
\end{tabular}

\subsection{Descriptive Statistics of Variables}

Table 4 is a descriptive statistic of the main variables. The average compensation of top three executives is 14.28 , labor intensive, technology-intensive and capital-intensive, respectively, and the standard deviation is less than 1, indicating that high executive pay is a common phenomenon in various industries. In terms of explanatory 
variables, the average net asset return is $7 \%$, close to the standard value of $8 \%$, which develops well. The average value of the performance decline variable is 0.33 , which indicates that $67 \%$ of A-share listed companies are in the state of rising performance, which is closely related to the steady and moderate growth trend of China's macro-economy in recent years. China's stock market and the economic trend of the linkage significantly enhanced. In terms of control variables, the average of the separation of two positions is 0.22 , which indicates that the phenomenon of both chairman and general manager of A-share listed companies is not common. The average percentage of independent directors is 0.37 , which generally meets the CSRC's requirements for "at least" in the board of directors of listed companies There must be a third of the independent directors. The average value of property right is 0.45 , indicating that nearly half of the A-share listed companies are state-owned, and the state-owned economy has always occupied a dominant position in the national economy. The average value of asset-liability ratio is 0.47 , but the standard deviation of asset-liability ratio of labor-intensive enterprises is large, so it is difficult to accurately control the overall risk of the industry.

Table 4. Variable descriptive statistics

\begin{tabular}{|c|c|c|c|c|c|c|c|c|}
\hline & \multicolumn{2}{|c|}{ All } & \multicolumn{2}{|c|}{ Labor-intensive enterprises } & \multicolumn{2}{|c|}{ Technology-intensive enterprises } & \multicolumn{2}{|c|}{ Capital intensive enterprise } \\
\hline & $\begin{array}{l}\text { mean } \\
\text { value }\end{array}$ & $\begin{array}{l}\text { standard } \\
\text { deviation }\end{array}$ & mean value & $\begin{array}{l}\text { standard } \\
\text { deviation }\end{array}$ & mean value & $\begin{array}{l}\text { standard } \\
\text { deviation }\end{array}$ & mean value & $\begin{array}{l}\text { standard } \\
\text { deviation }\end{array}$ \\
\hline$y_{1}$ & 14.28 & 0.71 & 14.33 & 0.76 & 14.27 & 0.67 & 14.23 & 0.69 \\
\hline$y_{2}$ & 14.37 & 0.70 & 14.41 & 0.75 & 14.36 & 0.67 & 14.31 & 0.66 \\
\hline roe & 0.07 & 0.57 & 0.07 & 0.55 & 0.06 & 0.62 & 0.07 & 0.43 \\
\hline$d$ & 0.33 & 0.47 & 0.35 & 0.48 & 0.32 & 0.47 & 0.33 & 0.47 \\
\hline ins & 0.87 & 3.58 & 0.92 & 4.00 & 0.73 & 2.43 & 1.17 & 5.08 \\
\hline res & 0.22 & 0.54 & 0.22 & 0.69 & 0.21 & 0.43 & 0.23 & 0.38 \\
\hline sen & 0.65 & 3.47 & 0.69 & 3.85 & 0.52 & 2.35 & 0.94 & 4.98 \\
\hline dual & 0.22 & 0.42 & 0.23 & 0.42 & 0.25 & 0.43 & 0.13 & 0.34 \\
\hline board & 0.37 & 0.05 & 0.37 & 0.06 & 0.37 & 0.05 & 0.37 & 0.05 \\
\hline state & 0.45 & 0.50 & 0.43 & 0.49 & 0.40 & 0.49 & 0.64 & 0.48 \\
\hline revenue & 119.38 & 864.29 & 119.95 & 485.54 & 75.75 & 275.29 & 249.18 & 1995.75 \\
\hline lev & 0.47 & 0.74 & 0.53 & 1.15 & 0.44 & 0.30 & 0.43 & 0.19 \\
\hline first & 35.85 & 15.54 & 35.13 & 15.17 & 34.79 & 15.36 & 40.75 & 16.04 \\
\hline hold & 0.25 & 0.90 & 0.25 & 0.98 & 0.29 & 0.92 & 0.11 & 0.60 \\
\hline
\end{tabular}

\subsection{Correlation Analysis}

The purpose of this paper is to test the correlation between main variables in a reasonable range by using Pearson correlation test. The results are shown in Table 5. It can be found that the correlation coefficient between the explanatory variable and the control variable is less than 0.5 , and it can be judged that there is no problem of multiple collinearity in the model.

Table 5. Pearson correlation test

\begin{tabular}{|c|c|c|c|c|c|c|c|c|c|c|c|c|c|c|}
\hline & $\mathrm{y} 1$ & $\mathrm{y} 2$ & roe & $d$ & ins & res & sen & dual & board & state & revenue & lev & first & hold \\
\hline $\mathrm{y} 1$ & 1 & & & & & & & & & & & & & \\
\hline y2 & $0.978 k k$ & 1 & & & & & & & & & & & & \\
\hline roe & $0.046 * k$ & $0.046 * \mathrm{kk}$ & 1 & & & & & & & & & & & \\
\hline $\mathrm{d}$ & $-0.114 k * k$ & $-0.112 k k$ & $-0.036 \mathrm{kk}$ & 1 & & & & & & & & & & \\
\hline ins & $0.152 k-k$ & $0.146 * k *$ & 0.007 & -0.01 & 1 & & & & & & & & & \\
\hline res & $0.222 k *$ & $0.218 k-k$ & $0.028 k-k$ & $-0.091 * k$ & $0.280 * k$ & 1 & & & & & & & & \\
\hline sen & $0.122 k k$ & $0.117 k-k$ & 0.003 & 0.004 & $0.989 * k *$ & $0.133 * k$ & 1 & & & & & & & \\
\hline dual & 0.004 & $-0.032 * k$ & -0.001 & $-0.046 * k \mathrm{k}$ & $-0.037 * * k$ & $-0.034 * k *$ & $-.033 * * k$ & 1 & & & & & & \\
\hline board & 0.003 & -0.004 & -0.002 & 0.007 & $0.054 k * k$ & $0.140 k-k$ & $0.034 * k$ & $0.112 k-k$ & 1 & & & & & \\
\hline state & $0.052 * k$ & 0.019 & -0.009 & $0.068 * k$ & $0.119 * k$ & $0.108 * k$ & $0.106 * k$ & $-0.263 * k$ & $-0.056 * *$ & 1 & & & & \\
\hline revenue & $0.105 k$ k & $0.100 * k-$ & 0.006 & -0.01 & $0.226 \mathrm{kk}$ & $0.276 * k$ & $0.191 k-k$ & $-0.036 * k=$ & $0.060 * k k$ & $0.096 k *$ & 1 & & & \\
\hline lev & 0.004 & 0.002 & $0.028 * k$ & 0 & $0.023 *$ & $0.026 *$ & 0.02 & $-0.037 k * k$ & 0.005 & $0.067 * k$ & $0.023 *$ & 1 & & \\
\hline first & $0.063 * k$ & $0.048 k \mathrm{k} k$ & $0.023 *$ & 0.01 & $0.089 *-k$ & $0.092 k-k$ & $0.077 * k$ & $-0.066 * k *$ & $0.034 * k$ & $0.197 * k$ & $0.149 * k *$ & -0.009 & 1 & \\
\hline hold & 0.079 k k k & $0.063 * k$ & 0.013 & -0.073 kk & -0.013 & $0.038 * k$ & -0.02 & $0.280 * k$ & $0.056 * k$ & $-0.228 * k k$ & -0.009 & $-0.027 *$ & $-0.036 * k$ & 1 \\
\hline
\end{tabular}

\subsection{Regression Analysis}

Table 6 shows the full sample regression results. From the regression results of model 1, we can see that the 
regression coefficient of performance variable roe is 0.149 , and has passed the double tail test of $1 \%$ significant level. The coefficient of interaction item roe $* \mathrm{~d}$ is significantly negative at the level of $1 \%$, and when the performance drops, The sensitivity coefficient of executive compensation $\left(\beta_{1}+\beta_{3}\right)$ is $-0.008(0.149-0.157)$, which indicates that when the performance of an enterprise rises, the executive pay increases by 14.9 percentage points, and when the performance of an enterprise drops, the executive compensation not only does not decrease, but also increases significantly by 0.8 percentage points. This is a common phenomenon in real society. According to the statistics of Choice, in 2016, 972 executives raised their salaries, of which 337 listed companies showed a decline in net profit, accounting for as much as 34 percent. This is closely related to the late start of the market-oriented process in China. The restraint mechanism of independent director is not perfect, and the standard of compensation and assessment is not clear, which makes the compensation of senior managers and the performance of enterprise production and management can not be absolutely linked. There is an asymmetric change in executive compensation when performance rises and falls. The interaction item ins $*$ roe $* \mathrm{~d}$ in model 2 is significantly negative at the level of $1 \%$, indicating that the organization does have the motivation to form strategic association with the executives. Support and encourage management to make decisions contrary to shareholders' goals, improve pay stickiness, and embezzle the company's long-term benefits. Therefore, the hypothesis $\mathrm{H} 1$ is verified in this paper.

Table 6. Institutional heterogeneity and executive pay stickiness

\begin{tabular}{|c|c|c|c|c|}
\hline Variable & Model 1 & Model 2 & Model 3 & Model 4 \\
\hline$c$ & $14.347 * * *$ & $14.380 * * *$ & $14.437 * * *$ & $14.360 * * *$ \\
\hline roe & $0.149 * * *$ & $0.132 * * *$ & $0.130 * * *$ & $0.141^{* * *}$ \\
\hline$d$ & $-0.157 * * *$ & $-0.135^{* * *}$ & $-0.132 * * *$ & $-0.147 * * *$ \\
\hline$r o e^{* d}$ & $-0.157 * * *$ & $-0.152 * * *$ & $-0.163^{* * *}$ & $-0.156^{* * *}$ \\
\hline ins & & 0.005 & & \\
\hline ins*roe & & $0.274 * * *$ & & \\
\hline ins $*$ roe $* d$ & & $-0.178 * * *$ & & \\
\hline res & & & $0.169 * * *$ & \\
\hline res*roe & & & $0.568^{* * *}$ & \\
\hline res*roe*d & & & $0.865^{* * *}$ & \\
\hline sen & & & & $0.006^{*}$ \\
\hline sen*roe & & & & $0.201 * * *$ \\
\hline $\operatorname{sen}^{*}$ roe $* d$ & & & & $-0.132 * * *$ \\
\hline dual & -0.001 & 0.003 & 0.009 & 0.001 \\
\hline board & -0.086 & -0.216 & $-0.409 * * *$ & -0.142 \\
\hline state & $0.099^{* * *}$ & $0.084^{* * * *}$ & $0.076^{* * *}$ & $0.089 * * *$ \\
\hline revenue & $0.000^{* * *}$ & $0.000 * * *$ & $0.000^{* * *}$ & $0.000^{* * *}$ \\
\hline lev & 0.001 & $-0.001^{* * *}$ & 0.000 & 0.000 \\
\hline firest & $0.002 * * *$ & $0.002 * * *$ & $0.002 * * *$ & $0.002 * * *$ \\
\hline hold & $0.060 * * *$ & 0.058 & $0.050^{* * *}$ & $0.060^{* * *}$ \\
\hline year & control & control & control & control \\
\hline$A d j-R$ & 0.057 & 0.079 & 0.097 & 0.069 \\
\hline$F$ & 37.8807 & 43.896 & 54.451 & 38.155 \\
\hline$N$ & 8489 & 8489 & 8489 & 8489 \\
\hline
\end{tabular}

***, **, * at the level of $1 \%, 5 \%, 10 \%$ respectively.

In order to verify hypothesis $\mathrm{H} 2$, the influence of heterogeneity institution holding on executive pay viscosity is investigated. According to whether there is a commercial relationship with listed company, the institution is divided into pressure-resistant institution and pressure-sensitive institution and regressed by grouping. The regression results of model 3 in Table 6 show that the coefficient of the interaction item res $*$ roe $* d$ is significantly positive at the level of $1 \%$, which is consistent with the expectation in this paper. It shows that the stress-resistant institutional investors who have no commercial relationship with listed companies can effectively exert their external supervisory functions, make prudent and objective decisions, and avoid self-interest and opportunistic behavior of management personnel. The viscosity of executive compensation plays a significant role in restraining effect. Model 4 show that the coefficient of the interaction item $\operatorname{sen} *$ roe $* d$ is significantly negative, which indicates that the stress-sensitive institutional investors will take a blind or disguised attitude to 
the decision-making of management for the purpose of self-interest, which has a significant positive effect on executive pay stickiness. In terms of control variables, there are significant differences in the ratio of assets and liabilities between model 2 and other models, and in the ratio of sole directors to directors in model 3 . The performance of other control variables is consistent on the level of symbol and significance, and there is no significant difference.

Table 7. Institutional heterogeneity, executive pay stickiness and factor intensity

\begin{tabular}{|c|c|c|c|c|c|c|}
\hline \multirow{2}{*}{ Variable } & \multicolumn{2}{|c|}{ Labor-intensive enterprises } & \multicolumn{2}{|c|}{ Technology-intensive enterprise } & \multicolumn{2}{|c|}{ Capital intensive enterprise } \\
\hline & Model 5 & Model 6 & Model 7 & Model 8 & Model 9 & Model 10 \\
\hline$c$ & $14.545^{* * *}$ & $14.502 * * *$ & $14.407 * * *$ & $14.386 * * *$ & $14.158 * * *$ & $14.208 * * *$ \\
\hline roe & $0.996 * * *$ & $0.998 * * *$ & $0.057 * * *$ & $0.071 * * *$ & $0.271 * * *$ & $0.296^{* * *}$ \\
\hline$d$ & $-0.093 * * *$ & $-0.090 * * *$ & $-0.112 * * *$ & $-0.147 * * *$ & $-0.099 * *$ & $-0.119 * * *$ \\
\hline $\begin{array}{c}r o e^{* d} \\
\quad \text { ins }\end{array}$ & $-1.034 * * *$ & $-1.030 * * *$ & $-0.077^{* *}$ & $-0.066^{* *}$ & $-0.313 * * *$ & $-0.317 * * *$ \\
\hline \multicolumn{7}{|l|}{ ins*roe } \\
\hline \multicolumn{7}{|l|}{ ins $*$ roe $* d$} \\
\hline res & $0.163 * * *$ & & $0.148^{* * *}$ & & $0.365^{* * *}$ & \\
\hline res*roe & -0.109 & & $1.021 * * *$ & & $0.898 * *$ & \\
\hline res*roe*d & $1.150^{* *}$ & & 0.358 & & 0.952 & \\
\hline sen & & 0.002 & & $0.018 * * *$ & & 0.007 \\
\hline sen*roe & & $0.128 * *$ & & 0.055 & & $0.202^{* *}$ \\
\hline sen*roe*d & & $-0.094 *$ & & $0.328 * * *$ & & -0.131 \\
\hline dual & 0.016 & 0.012 & 0.002 & 0.001 & -0.052 & -0.070 \\
\hline board & $-0.823 * * *$ & $-0.676^{* * *}$ & -0.224 & -0.086 & 0.171 & 0.181 \\
\hline state & $0.078 * * *$ & $0.087 * * *$ & $0.047 * *$ & $0.045^{*}$ & $0.180 * * *$ & $0.212^{* * *}$ \\
\hline revenue & $0.000 * * *$ & $0.000 * * *$ & $0.000^{* * *}$ & $0.000^{* * * *}$ & 0.000 & $0.000^{* * * *}$ \\
\hline$l e v$ & $-0.023 * *$ & $-0.023 * *$ & -0.021 & -0.020 & -0.124 & -0.154 \\
\hline firest & $0.003 * * *$ & $0.003^{* * *}$ & 0.000 & 0.000 & -0.001 & 0.000 \\
\hline hold & $0.024^{*}$ & $0.030^{* *}$ & $0.069^{* * *}$ & $0.079 * * *$ & 0.016 & 0.021 \\
\hline year & control & control & control & control & control & control \\
\hline $\operatorname{Adj}-R$ & 0.110 & 0.101 & 0.139 & 0.112 & 0.122 & 0.069 \\
\hline$F$ & 24.184 & 22.131 & 38.834 & 30.340 & 11.785 & 6.725 \\
\hline$N$ & 3197 & 3197 & 3971 & 3971 & 1321 & 1321 \\
\hline
\end{tabular}

***,**,* at the level of $1 \%, 5 \%, 10 \%$ respectively.

In order to verify hypothesis $\mathrm{H} 3$, the effect of heterogeneous institutional investors on executive pay stickiness of different types of listed companies is studied. This paper further divides the listed companies according to factor intensity, and the results of grouping regression are shown in Table 7. As can be seen from the regression results in Table 7, the interaction terms of labor-intensive and capital-intensive enterprisesroe $* \mathrm{~d}$ are significantly negative at the level of $1 \%$, and those of technology-intensive enterprise roe $* \mathrm{~d}$ are significantly negative at the level of 5\%. It shows that the increase in executive compensation is greater than the decline in performance, and the stickiness of executive pay is a common phenomenon in various industries. Model 4 in Table 7 shows that in labour-intensive enterprises, the coefficient of interaction res $*$ roe $* d$ is 1.150 , and the test of a significant level of $1 \%$ has been passed. It shows that the pressure resistant institutional investors play a significant role in restraining the executive pay stickiness in labor-intensive enterprises. While in technology-intensive and capital-intensive enterprises, the inhibition effect is not significant. It shows that the pressure resistant institutional investors have the courage to shoulder social responsibility, actively participate in the internal governance of labor-intensive enterprises, effectively control the short-sighted behavior of management personnel, protect the rights and interests of the broad masses of grass-roots workers, help loss-making enterprises to turn losses into profits and encourage labor intensive Type-A enterprises through technological innovation to promote the development of high-quality productivity. According to the model 8 of Table 7, the coefficient of interaction item sen $*$ roe $* \mathrm{~d}$ is 0.328 , which is significantly positive at the level of $1 \%$, which indicates that the stress-sensitive institutional investors participate actively in the internal governance and management decisions of technology-intensive enterprises for the consideration of investment returns, play a 
good role in assessment and supervision, and play a significant role in restraining the stickiness of executive compensation in technology-intensive enterprises. According to model 6 and model 10, the coefficient of interaction term $\operatorname{sen} *$ roe $* \mathrm{~d}$ is -0.094 and -0.131 , respectively, which indicates that stress-sensitive institutional investors with commercial ties with listed companies play a positive role in promoting the stickiness of executive compensation in labor-intensive and capital-intensive enterprises. As a result, the investment institutions can not make independent and objective decisions, which makes the executives who aim to maximize their own interests have the opportunity, which is not conducive to the long-term development of enterprises. Hypothesis $\mathrm{H} 3$ is verified.

\subsection{Robustness Test}

This paper selects the total compensation of directors, supervisors and top three executives as the substitute variable of the top three total compensation, and puts it back into the model. The results of robustness test are basically consistent with the original results. Due to space constraints, the results of robustness test are not listed in this paper.

\section{Conclusions and Recommendations}

Based on the data of Shanghai and Shenzhen A-share listed companies from 2012 to 2016, this paper empirically studies the influence of heterogeneous institutional investors on executive compensation stickiness of listed companies by using the method of multiple regression. The main conclusions are as follows: (1) Pay stickiness is common in listed companies. The ownership of institutional investors as a whole positively promotes the stickiness of executive compensation. (2) According to whether there is a business relationship between institutional investors and listed companies, they are classified as pressure resistant institutional investors and pressure sensitive institutional investors. Compared with stress-sensitive institutions, stress-resistant institutional investors can significantly curb executive compensation (3) Different types of institutional investors have different preferences for the types of listed companies, and stress-resistant institutional investors pay more attention to the long-term performance of labor-intensive enterprises out of social responsibility. Therefore, the stickiness of executive compensation has a significant inhibitory effect, while the stress-sensitive institutional investors actively participate in the internal governance of technology-intensive enterprises for the consideration of investment returns. As a result, the viscosity of executive compensation in technology-intensive enterprises has an inhibitory effect.

Based on the above conclusions, the text puts forward two policy recommendations: in order to protect the legitimate rights and interests of the majority of investors, especially small and medium-sized investors, regulators should improve the executive compensation information disclosure system in listed companies. It is not only required to disclose the changes of executive compensation in listed companies, but also to refine the salary formulation and performance evaluation standards, to ensure the transparency of disclosure information and to avoid the phenomenon of "decoupling" between management personnel and company performance. It is also necessary to establish the corresponding incentive system and restraint mechanism within the company, give reasonable remuneration by giving scientific, reasonable, fair and just evaluation to the performance of senior management and give reasonable rewards and incentives. In terms of institutional investors, legislative departments and regulatory authorities should actively use administrative and legal means to regulate the investment behavior and business scope of institutional investors, and establish a strict supervision mechanism of prior prevention, supervision in matters, and investigation and punishment afterwards. In the process of planning and implementing the cooperation between listed companies and professional investment institutions, we should establish an effective mechanism to prevent the transmission of interests and conflicts of interests, improve the information isolation mechanism, and step up the crackdown on illegal activities such as insider trading and market manipulation to ensure the independence and effectiveness of institutional investors in performing external oversight functions.

\section{Acknowledgment}

The authors are thankful to the Student's Platform for Innovation and Entrepreneurship Training Program (code: 201810559085, 201810559093).

\section{References}

Almazan, A. (2005). Active institutional shareholders and costs of monitoring: Evidence from executive compensation. Financial Management, (4), 5-34. https://doi.org/10.1111/j.1755-053X.2005.tb00116.x

Bebchunk, L. A. (2002). Managerial power and rent extraction in the design of executive compensation. University of China-go Law Review, 69(7), 751-846. https://doi.org/10.2307/1600632 
Bemard, S. B. (1992).. The balue of institutional investor monitoring: The empirical ebidence. UCLA Law Review, 39, 895-939.

Bhide, A.(1993). The Hidden Costs of Stock Market Liquidity. The Journal of Finance, 34(1), 31-51. https://doi.org/10.1016/0304-405X(93)90039-E

Brikley, J., Lease, R., \& Smith, C. (1988). Ownership structure and voting on anti takeover amendments. Journal of Financial Economics, 20(2), 237-265.

Chen, J. (2017). Heterogeneity of institutional investors, private communication and corporate governance. Graduate School of the Chinese Academy of Social Sciences.

Chen, X. L., Song, X. N., \& Lou, Y. (2007). An empirical Analysis of the effect of Institutional Investor holding on the Transparency of listed companies. Economic Forum, (18), 111-116.

Cox, P., Brammer, S., \& Millington, A. (2007). Pension Funds and Corporate Social Performance An Empirical Analysis. Business \& Society, 47(2), 213-241. https://doi.org/10.1177/0007650306297945

David, P. (1998). The Effect of Institutional Investors on the Level and Mix of CEO Compensation. Academy of Management Journal, (2), 200-208. https://doi.org/10.5465/257102

Fang, J. X. (2009). Is there stickiness in executive compensation of listed companies in China? Economic Studies, 44(03), 110-124.

He, B. F., Fang, S., \& Feng, J. (2017). Empirical Study on Energy Conservation, Emission Reduction and Stable Growth Based on Factor Intensity of Industry. Industrial Technology Economy, 36(01), 10-14.

Jackson, S., Lopez, T., \& Reitenga, A. (2008). Accounting fundamental and CEO bonus compensation. Journal of Accounting and Public Policy, 27(5), 374-393. https://doi.org/10.1016/j.jaccpubpol.2008.07.006

Khorana, A., Servaes, H., \& Tufano, P. (2005). Explaining the Size of the Mutual Fund Industry around the World. Journal of Financial Economics, 78(1), 145-185. https://doi.org/10.1016/j.jfineco.2004.08.006

Leone, A., Wu, J., \& Zimmerman, J. (2006). Asymmetric sensitivity of CEO cash compensation to stock re-turns. Journal of Accounting and Economics, 42(1), 167-192. https://doi.org/10.1016/j.jacceco.2006.04.001

Lerner, J. (1995). Venture capitalists and the oversight of private firms. Journal of Finance, 50(1), 301-318. https://doi.org/10.1111/j.1540-6261.1995.tb05175.x

Li, S. M., \& Ye, H. (2007). An Analysis of the difference between Equity structure and Corporate performance-based on the Industrial Factor intensity. Stock Market Bulletin, (04), 35-43.

Li, W. J., \& Kong, D. M. (2013). Information transparency, corporate governance and minority shareholder participation. Accounting Research, (01), 42-49.

Lu, R. (2008). Management Power, compensation and performance sensitivity Analysis-empirical evidence from listed companies in China. Contemporary Finance \& Economics, (07), 107-112.

Lu, T., \& Dang, Y. (2014). Corporate governance and technological innovation: Comparison by industry. Economic Studies, (06), 115-128.

Luo, J. B. (2016). Heterogeneity of Institutional investors CEO's political relevance and earnings Management. Accounting and Economic Research, 30(01), 52-77.

Pound, J. (1988). Proxy contests and the efficiency of shareholder oversight. Journal of Financial Economics, (2), 80-102. https://doi.org/10.1016/0304-405X(88)90046-3

Shin, J. Y. (2008). Institutional investment horizons and CEO compensation. Working Paper, University of Illinois. https://doi.org/10.2139/ssrn.773690

Shleifer, A., \& Vishny, R. (1986). Large shareholders and corporate control. Journal of Political Economy, (94), 461-488. https://doi.org/10.1086/261385

Song, Y. Y., \& Tang, Y. J. (2009). Will institutional investors help improve corporate performance? Empirical evidence from Chinese listed companies in 2003-2007. South Economy, (12), 56-68.

Wang, K. M., \& Wang, Z. C. (2007). Executive Control, compensation and earnings Management: an empirical study based on Chinese listed companies. Managing the World, (07), 111-119.

Wang, X. H., Liu, L. J., \& Wang, Q. (2018). Study on the influence of heterogeneous Institutional Investor's shareholding on financing constraint. Journal of Nanjing Audit University, (01), 69-78. 
Wu, X. C. (2015). Does institutional investor influence executive compensation and its private income? a study based on different characteristics of institutional investors. Foreign Economy and Management, 37(08), 13-29.

Xia, X. H. (2014). Debt maturity structure, property rights and executive pay stickiness. Science and Technology and Economy, (1), 106-110.

Xiao, X., \& Wang, K. (2005). Securities Investment funds: investors or speculators? World Economy, (08), 75-81.

Yan, L. M., \& Tang, Q. Q. (2015). Are institutional investors more active supervisors: Evidence from the gem. Journal of Guangdong University of Finance and Economics, 01, 96-103.

Yang, D. (2016). The influence of institutional investor heterogeneity on accounting conservatism. Xiangtan University.

Yu, N. T., Lu, K. S., \& Xie, H. B. (2017). Heterogeneity of Institutional Investors, Accruals and Real Earnings Management. Journal of Jiangxi University of Finance and Economics, (05), 36-47.

Zhang, A. M., Sang, Y. Y., \& Lu, Y. S. (2016). Political connection, property right Nature and executives' compensation stickiness: Empirical evidence from Shanghai and Shenzhen A-share listed companies. Accounting and Economic Research, 30(02), 54-66.

Zhang, M., \& Jiang, F. X. (2010). Institutional Investor, Enterprise property and compensation contract. World Economy, 33(08), 43-58.

Zheng, X. T., \& Xu, Y. B. (2013). The behavior Choice of small and Medium-sized shareholders under controlling shareholder's seizing Private profit-"rational indifference" or "active Supervision"? Economic Review, (06), 11-16.

\section{Copyrights}

Copyright for this article is retained by the author(s), with first publication rights granted to the journal.

This is an open-access article distributed under the terms and conditions of the Creative Commons Attribution license (http://creativecommons.org/licenses/by/4.0/). 